\title{
Hubungan Pengetahuan dan Sikap Pasien dengan Kepatuhan Penatalaksanaan Diabetes Melitus di Poliklinik Khusus Penyakit Dalam RSUP Dr. M. Djamil Padang
}

\author{
Mohd Jamil*, Dorisnita, Linda Ardayanti \\ Fakultas keperawatan Universitas Andalas \\ *Correspondence email: mohdjamil@nrs.unand.ac.id
}

\begin{abstract}
Abstrak. Kepatuhan penatalaksanaan diabetes melitus merupakan aspek penting dalam mengendalikan kadar gula darah. Kepatuhan tidak terlepas dari pengetahuan dan sikap individu karena factor tersebut sebagai pendorong utama dalam membentuk suatu perilaku. Penelitian ini bertujuan untuk mengetahui hubungan pengetahuan dan sikap dengan kepatuhan penatalaksanaan diabetes militus. Penelitian ini dilakukan di poliklinik khusus penyakit dalam RSUP Dr. M.Djamil Padang. Desain ini adalah penelitian kuantitatif dengan cross sectional yang dilakukan pada 49 responden dengan teknik purposive Sampling. Hasil uji statistic menggunakan chi-square didapatkan $p$ value yaitu 0,031 dan 0,000 artinya terdapat hubungan yang bermakna antara pengetahuan dan sikap pasien dengan kepatuhan penatalaksanaan diabetes melitus. Diharapkan tenaga kesehatan dapat meningkatkan kepatuhan pasien dalam penatalaksanaan diabetes mellitus melalui program pendidikan kesehatan yang optimal.
\end{abstract}

Kata kunci: kepatuhan; pengetahuan; sikap; penatalaksanaan; diabetes

\begin{abstract}
Diabetes Mellitus management compliance in the important aspect in controlling blood sugar levels. Compliance is inseparable from the knowledge and attitudes of individuals because these factors are the main drivers in shaping a behavior. This study aims to determine the relationship between knowledge and attitudes of patients with adherence to diabetes mellitus management in a specific polyclinic in RSUP DR. M. Djamil Padang. This research was conducted in a special clinic for internal medicine Dr. M. Djamil Padang. This research is a quantitative research with crosssectional -conducted on 49 respondents using the purposive Sampling. The results of statistical tests using the chi-square obtained p value, namely 0.031 and 0.000, which means that there is a significant relationship between knowledge and attitudes of patients with adherence to diabetes mellitus management. It is hoped that health services can improve patient compliance in diabetes mellitus management through optimal health education programs.
\end{abstract}

Keywords: Attitude; Compliance; Knowledge; diabetes; management

\section{PENDAHULUAN}

Diabetes Melitus (DM) merupakan penyakit menahun yang ditandai dengan kadar glukosa darah melebihi normal (Atlas, 2015). Penyakit ini ditandai dengan hiperglikemi akibat kelainan kerja pada insulin, sehingga terjadi penumpukan karbohidrat dalam bentuk glukosa yang mengakibatkan peningkatan gula dalam darah (Smeltzer \& Bare, 2010). Diabetes adalah masalah kesehatan masyarakat yang penting, karena jumlah kasus dan prevalensi diabetes terus meningkat selama beberapa dekade terakhir (WHO, 2018). Prevalensi DM seluruh dunia tercatat sebesar 382 juta orang, berumur 40-59 tahun, dan diperkirakan akan terus meningkat setiap tahunnya (IDF, 2018)

WHO (2018) menyatakan kenaikan jumlah penduduk dunia yang terkena penyakit diabetes semakin mengkhawatirkan. Pada tahun 2000 jumlah penduduk dunia yang menderita diabetes sudah mencapai 171.230.000 orang, dan pada tahun 2030 diperkirakan akan mencapai jumlah 366.210 .100 orang atau naik sebesar $114 \%$ dalam kurun waktu 30 tahun. Secara global, lebih dari 422 juta orang dewasa hidup dengan diabetes pada tahun 2018, dibandingkan dengan 108 juta pada tahun 1980. Prevalensi diabetes di dunia (dengan usia yang distandarisasi) telah meningkat hampir dua kali lipat sejak tahun 1980 , dari 4,7\% menjadi $8,5 \%$ pada populasi orang dewasa.

Menurut Muhith \& Setyowati (2014) penyebab kenaikan gula darah yaitu makanan yang tinggi karbohidrat, tinggi lemak, rendah serat, banyak mengandung gula, banyak mengandung protein, obesitas, kurang olahraga (latihan fisik) dan pola nutrisi yang salah (serba instan).

Penatalaksanaan DM dimulai dengan menerapkan pola hidup sehat (terapi nutrisi dan latihan fisik) bersama dengan terapi farmakologi. Tujuan penatalaksanaan DM secara umum adalah meningkatkan kualitas hidup penyandang DM, tujuan jangka pendek yaitu menghilangkan keluhan, memperbaiki kualitas hidup dan mengurangi resiko komplikasi. Sedangkan tujuan akhir dari penatalaksanaan DM adalah turunnya angka morbiditas dan mortalitas DM (PERKENI, 2019).

Kepatuhan melaksanakan terapi nutrisi, terapi farmakologi dan latihan fisik pada penderita DM menjadi salah satu hal yang penting dalam penatalaksanaan karena seringkali penderita tidak memperhatikan asupan makanan yang seimbang dan 
juga penolakan pada terapi insulin (Pradipta et al., 2013).

Hasil penelitian Hassan dkk (2013) terhadap 36 penderita DM sebagian besar $(55,6 \%)$ tidak patuh terhadap diet. Penelitian Phitri dan Widiyaningsih (2013) pada 54 penderita DM di RSUD AM Parikesit Kalimantan Timur didapatkan hasil $(57,4 \%)$ tidak patuh terhadap diet. Menurut hasil penelitian Journal Investigation Diabetes (2020), alasan penederita menolak melakukan terapi insulin karena harganya yang mahal dan ketidaktahuan pasien tentang terapi ini. Penderita penyakit diabetes melitus $80 \%$ diantaranya menyuntik insulin dengan cara yang tidak tepat 5,8\% memakai dosis yang salah, $75 \%$ tidak mengikuti diet yang dianjurkan. Ketidakpatuhan ini merupakan salah satu hambatan untuk tercapainya tujuan pengobatan. Hasil penelitian diatas menunjukkan bahwa kepatuhan diet penderita DM sebagian besar dalam kategori kurang (Rudini, 2017).

Untuk itu pengetahuan pasien terhadap penatalaksaan Diabetes Melitus sangat diperlukan dalam menghadapi penyakit ini. Pasien yang memiliki pengetahuan yang rendah maka sikap dan kepatuhannya terhadap pengobatan Diabetes Melitus juga rendah (Jaya et al, 2019). Hasil penelitian Herath et al (2017) bahwa dari 277 responden dengan diabetes melitus memiliki tingkat pengetahuan yang rendah yaitu $39 \%$.

Selain pengetahuan, kecenderungan seseorang untuk berprilaku dipengaruhi oleh sikap. Sikap adalah sesuatu yang berhubungan dengan persepsi tingkah laku dan sikap perbuatan yang didasari oleh keyakinan berdasarkan norma-norma yang di masyarakat bisanya norma agama (Notoadmodjo, 2012).

Hasil penelitian Okatiranti dan Hardiyanti (2016) didapatkan gambaran sikap pasien terhadap penatalaksanaan DM adalah $(59,32 \%)$ bersikap positif, dan $(40,67 \%)$ bersikap negatif. Penelitian Kirehe District Hospital (2017) tingkat pengetahuan dan sikap pasien diabetes melitus tergolong rendah dan sangat mempengaruhi bagaimana mereka menjalani terapi.

Kegagalan dalam mengikuti program pengobatan jangka panjang yang bukan dalam kondisi akut, ditemukan derajat ketidakpatuhanya rata-rata $50 \%$ dan derajat tersebut bertambah buruk seiring berjalanya waktu (Niven, 2013).

\section{METODE}

Jenis penelitian ini adalah kuantitatif dengan menggunakan desain cross sectional. Populasi dalam penelitian ini adalah seluruh pasien yang didiagnosa dengan DM di Poliklinik Khusus Penyakit Dalam RSUP Dr.M.Djamil Padang.

Jumlah sampel adalah 56 orang pasien. Teknik pengambilan sampel dengan menggunakan Purposive Sampling, Kriteria inklusi yakni pasien yang didiagnosa dengan diabetes melitus, Mampu berkomunikasi dengan baik dan Pasien yang sudah mendapatkan edukasi kesehatan. Pengambilan data dilakukan dengan menggunakan kuesioner. Hasil uji kuesioner didapatkan untuk variabel pengetahuan didapatkan nilai validitaas $0,45-0,91$. Hasiluji kuesioner variable sikap didapatkan nilai validitas $0,42-0,82$. Sedangkan untuk variable kepatuhan didapatkan nilai validitas $0,43-0,86$.

\section{HASIL DAN PEMBAHASAN}

Tabel 1. Distribusi Frekuensi Karakteristik Responden di Poliklinik Khusus Penyakit Dalam RSUP Dr. M. Djamil Padang $(n=49)$

\begin{tabular}{lll}
\hline Karakterisitik responden & $\mathrm{F}$ & $\%$ \\
\hline Jenis Kelamin & & \\
Laki-laki & 18 & 36,7 \\
Perempuan & 31 & 63,3 \\
Pendidikan & & \\
SD & 1 & 2,0 \\
SMP & 20 & 40,8 \\
SMA & 23 & 46,9 \\
Perguruan tinggi & 5 & 10,2 \\
Usia & & \\
Dewasa Madya (41-60 thn) & 41 & 83,7 \\
Lansia (>60) & 8 & 16,3 \\
Total & 84 & 100 \\
\hline
\end{tabular}

Berdasarkan tabel 1 bahwa responden berjenis kelamin laki laki yaitu $36,7 \%$, pendidikan responden paling rendah yaitu tingkat SD (2,0\%), Sebanyak 16,3\% responden berusia $>60$ tahun (lansia).

Tabel 2. Distribusi Frekuensi Tingkat Kepatuhan Pasien Mengenai Penatalaksanaan Diabetes Mellitus Di Poliklinik Khusus Penyakit Dalam RSUP Dr. M. Djamil Padang ( $\mathrm{n}=49)$

\begin{tabular}{lll}
\hline Tingkat Kepatuhan & $\mathrm{F}$ & $\%$ \\
\hline Patuh & 28 & 57,1 \\
Tidak Patuh & 21 & 42,9 \\
TOTAL & 49 & 100 \\
\hline
\end{tabular}

Berdasarkan tabel 2 bahwa terdapat $(42,9 \%)$ memiliki tingkat kepatuhan pada kategori tidak patuh terhadap penatalaksanaan diabetes mellitus. Hasil studi lain mengenai kepatuhan pasien untuk menjalani terapi insulin lebih dari $33 \%$ pasien DM menolak insulin, walaupun sudah sudah disarankan untuk menggunakan insulin (Lestari, 2014).

Menurut Journal Investigation Diabetes (2020), alasan penederita menolak melakukan terapi insulin karena harganya yang mahal dan ketidaktahuan pasien tentang terapi ini. Penderita penyakit diabetes melitus $80 \%$ diantaranya menyuntik insulin dengan cara yang tidak tepat 5,8\% memakai dosis yang salah, $75 \%$ tidak mengikuti diet yang dianjurkan. 
Mohd Jamil, Dorisnita dan Linda Ardayanti, Hubungan Pengetahuan dan Sikap Pasien dengan Kepatuhan Penatalaksanaan Diabetes Melitus di Poliklinik Khusus Penyakit Dalam RSUP Dr. M. Djamil Padang

Tabel 3. Distribusi Frekuensi Tingkat Pengetahuan Pasien Mengenai Penatalaksanaan Diabetes Mellitus Di Poliklinik Khusus Penyakit Dalam RSUP Dr. M. Djamil Padang (n=49)

\begin{tabular}{lll}
\hline Tingkat Pengetahuan & $\mathrm{f}$ & $\%$ \\
\hline Baik & 25 & 51,0 \\
Kurang & 24 & 49,0 \\
TOTAL & 49 & 100 \\
\hline
\end{tabular}

Berdasarkan tabel 3 terdapat $49,0 \%$ responden memiliki tingkat pengetahuan yang kurang terhadap penatalaksanaan diabetes melitus.

Hasil penelitian Lestari (2014) memperlihatkan kecenderungan penolakan insulin dilakukan oleh pasien yang memiliki pengetahuan rendah dengan melihat hasil bahwa pasien DM yang memiliki pengetahuan baik $33,7 \%$ menerima insulin dan pasien DM yang memiliki pengetahuan kurang 77,6\% menolak insulin.

Pengetahuan yang baik di butuhkan untuk menentukan sikap pasien terhadap terapi yang sedang ia jalani baik itu terapi insulin ataupun menjalankan diet yang sedang disarankan untuknya (Al Zarea, 2016).

Tabel 4. Distribusi Frekuensi Sikap Pasien Mengenai

Penatalaksanaan Diabetes Mellitus Di Poliklinik Khusus

Penyakit Dalam RSUP Dr. M. Djamil Padang Tahun 2020

\begin{tabular}{|c|c|c|}
\hline & & \\
\hline Sikap & $f$ & $\%$ \\
\hline Positif & 24 & 49,0 \\
\hline Negatif & 25 & 51,0 \\
\hline TOTAL & 49 & 100 \\
\hline
\end{tabular}

Berdasarkan tabel 4 terdapat $(51,0 \%)$ responden memiliki sikap yang negative terhadap penatalaksanaan diabetes mellitus.

Menurut Kirehe District Hospital (2017) sikap pasien diabetes melitus masih tergolong rendah dan sangat mempengaruhi bagaimana mereka menjalani terapi.

Memon et al (2015) dalam penelitiannya menyebutkan bahwa Sikap pasien yang positif dapat mendorong pasien tersebut untuk berperilaku positif terhadap kepatuhan terhadap penatalaksanaan diabetes melitus untuk mengontrol kadar gula darah dan mencegah terjadinya komplikasi diabetes mellitus baik itu komplikasi akut maupun komplikasi kronik

Tabel 5. Hubungan Tingkat Pengetahuan Pasien Dengan Kepatuhan Penatalaksanaan Diabetes Mellitus Di Poliklinik Khusus Penyakit Dalam RSUP Dr. M. Djamil Padang (N=49)

\begin{tabular}{llllllll}
\hline \multirow{3}{*}{ Pengetahuan } & \multicolumn{6}{c}{ Kepatuhan } & P \\
\cline { 2 - 7 } & \multicolumn{2}{c}{ Patuh } & \multicolumn{4}{c}{ Tidak patuh } & \multicolumn{2}{c}{ Total } & \\
\cline { 2 - 7 } & $f$ & $\%$ & $F$ & $\%$ & $F$ & $\%$ & \\
\hline Baik & 18 & 72,0 & 7 & 28,0 & 25 & 100 & \\
Kurang & 10 & 41,7 & 14 & 58,3 & 24 & 100 & 0,031 \\
Total & 28 & 57,1 & 21 & 42,9 & 49 & 100 & \\
\hline
\end{tabular}

Berdasarkan tabel 5 menunjukkan bahwa terdapat hubungan antara tingkat pengetahuan pasien dengan kepatuhan Penatalaksanaan Diabetes Mellitus Di Poliklinik Khusus Penyakit Dalam RSUP Dr. M. Djamil Padang Tahun 2020, dari 24 responden yang memiliki pengetahuan kurang 10 responden $(41,7 \%)$ diantaranya patuh dan 14 responden $(58,3 \%)$ diantaranya tidak patuh dalam penatalaksanaan diabetes.

Hal ini disebabkan karena responden dengan tingkat pengetahuan kurang tidak mengindikasikan bahwa responden tersebut tidak memiliki pengetahuan. Akan tetapi, dengan tingkat pengetahuan yang dimiliki, responden masih memiliki sikap patuh. Terdapat 25 responden yang memiliki pengetahuan baik, 18 responden $(72,2 \%)$ patuh dan 7 responden $(28,0 \%)$ tidak patuh dalam penatalaksaan diabetes melitus, Hal ini disebabkan karena responden dengan pengatahuan yang baik tidak menjamin responden tersebut bersikap patuh.

Hasil uji statistik chi square didapatkan nilai $\mathrm{p}=$ 0,031 ( $\mathrm{p}<0,05$ ). Maka disimpulkan bahwa terdapat hubungan yang bermakna antara tingkat pengetahjuan pasien dengan kepatuhan Penatalaksanaan Diabetes Mellitus.

Saturnus (2015) memaparkan beberapa penelitian bahwa kurangnya pengetahuan tentang DM menyebabkan pasien tidak patuh dalam menjalani diet dan pasien cenderung menolak terapi insulin. Penyebab penderita tidak patuh dalam menjalani diet karena tidak memahami manfaat diet (Reach, 2011). Penelitian yang dilakukan di Mesir j menyebutkan bahwa pasien yang menjalani terapi insulin tidak memiliki pengetahuan yang baik terhadap diabetes melitus (Khawaga, 2015).

Tabel 6. Hubungan Sikap Pasien Dengan Kepatuhan Penatalaksanaan Diabetes Mellitus Di Poliklinik Khusus Penyakit Dalam RSUP Dr. M. Djamil Padang (N=49)

\begin{tabular}{|c|c|c|c|c|c|c|c|}
\hline \multirow{3}{*}{ Sikap } & \multicolumn{6}{|c|}{ Kepatuhan } & \multirow{3}{*}{$\begin{array}{l}\mathrm{p} \\
\text { Value }\end{array}$} \\
\hline & \multicolumn{2}{|c|}{ Patuh } & \multicolumn{2}{|c|}{ Tidak patuh } & \multicolumn{2}{|c|}{ Total } & \\
\hline & $f$ & $\%$ & $F$ & $\%$ & $f$ & $\%$ & \\
\hline Positif & 20 & 83,3 & 4 & 16,7 & 24 & 100 & 0 \\
\hline Negatif & 8 & 14,3 & 17 & 68,0 & 25 & 100 & 0,000 \\
\hline Total & 28 & 57,1 & 21 & 42,9 & 49 & 100 & \\
\hline
\end{tabular}

Berdasarkan tabel 6 menunjukkan dari 24 responden yang memiliki sikap positif 20 responden $(83,3 \%)$ diantaranya patuh dan 4 responden $(16,7 \%)$ diantaranya tidak patuh dalam penatalaksanaan diabetes. Hal ini disebabkan karena responden dengan sikap positif tidak menjamin responden tersebut bersikap patuh. Dari 25 responden yang memiliki sikap negatif, 8 responden $(14,3 \%)$ patuh dan 17 responden $(68,0 \%)$ tidak patuh dalam penatalaksaan diabetes melitus.

Hal ini disebabkan karena responden dengan sikap negatif tidak mengindikasikan bahwa responden tersebut tidak sepenuhnya menolak sikap terhadap penatalaksanaan diabetes melitus. Akan tetapi, dengan sikap negatif yang dimiliki, responden masih menerima beberapa sikap terhadap penatalaksanaan diabetes melitus. 
Didapatkan data bahwa hasil uji statistik chi square didapatkan nilai $\mathrm{p}=0,000(\mathrm{p}<0,05)$, maka disimpulkan bahwa terdapat hubungan yang bermakna antara sikap pasien dengan kepatuhan Penatalaksanaan Diabetes Mellitus. Penelitian Asmamaw et al. (2019) mengatakan bahwa sikap seseorang sangat mempengaruhi seseorang untuk melakukan terapi nutrisi, terapi farmakologi dan latihan fisik.

Sikap yang baik terhadap pengendalian dan manajemen diri pada pasien DM dapat mengoptimalkan Kesehatan pada penderita DM (Powers, 2015). Penelitian Alsous, Jalil, Odeh, Kurdi, \& Alnan, 2019 terhadap pasien yang mengalami diabetes mellitus secara signifikan menunjukkan hubungan antara sikap dan kepatuahan dengan nilai $\mathrm{p} 0,000$. Sikap yang negative serta penatalaksanaan yang tidak tepat pada penderita DM sangat memungkinkan untuk menimbulkan komplikasi (Nathan, 2019).

\section{SIMPULAN}

Hasil penelitian menunjukkan karakteristik responden berjenis kelamin laki- laki yaitu 36,7\%, pendidikan responden paling sedikit yaitu pada tingkat SD $(2,0 \%)$, Sebanyak $16,3 \%$ responden berusia > 60 tahun (lansia). Terdapat (42,9\%) memiliki tingkat kepatuhan pada kategori tidak patuh terhadap penatalaksanaan diabetes mellitus. Ada 49,0 \% responden memiliki tingkat pengetahuan yang kurang terhadap penatalaksanaan diabetes melitus. Terdapat $(51,0 \%)$ memiliki sikap yang negatif terhadap penatalaksanaan diabetes mellitus. Terdapat hubungan yang bermakna antara tingkat pengetahuan pasien dengan kepatuhan Penatalaksanaan Diabetes Mellitus. Terdapat hubungan yang bermakna antara sikap pasien dengan kepatuhan Penatalaksanaan Diabetes Melitus.

Dengan hasil penelitian ini dapat memberikan tambahan informasi ilmu keperwatan mengenai hubungan pengetahuan dan sikap pasien terhadap kepatuhan penatalaksanaan diabetes melitus

\section{DAFTAR PUSTAKA}

Alsous, M., Jalil, M. A., Odeh, M., Kurdi, R. Al, \& Alnan, M. (2019). Public knowledge, attitudes and practices toward diabetes mellitus: A crosssectional study from Jordan. PLoS ONE, 14(3), 112. https://doi.org/10.1371/journal.pone.0214479

Al Zarea BK. 2016. Knowledge, Attitude and Practice of Diabetic Retinopathy amongst the Diabetic Patients of AlJouf and Hail Province of Saudi Arabia. J Clin Diagn Res. 2016;10:NC05-NC08

Atlas, D. (2015). International diabetes federation. IDF Diabetes Atlas, 7th edn. Brussels, Belgium: International Diabetes Federation..

American Diabetes Association (ADA). (2019). Standard medical care in diabetes 2019. American Diabetes Association (ADA).
Asmamaw, T., Genet, S., Menon, M., Tarekegn, G., Chekol, E., Geto, Z., ... \& Tolcha, Y. (2020). Early Detection of Renal Impairment Among Patients with Type 2 Diabetes Mellitus Through Evaluation of Serum Cystatin C in Comparison with Serum Creatinine Levels: A Cross-Sectional Study. Diabetes, Metabolic Syndrome and Obesity: Targets and Therapy, 13, 4727.

Brunner, L. S., Smeltzer, S. C. O. C., Bare, B. G., Hinkle, J. L., \& Cheever, K. H. (2010). Brunner \& Suddarth's Textbook of Medical-surgical Nursing (Issue v. 1). Wolters Kluwer Health/Lippincott Williams \& Wilkins. https://books.google.co.id/books?id=SmtjSD1 x68 $8 \mathrm{C}$

Khawaga, G., \& Abdel-Wahab, F. (2015). Knowledge, Attitudes, Practice And Compliance Of Diabetic Patients In Dakahlia, Egypt. 3(1), 14.

Hassan, H. A., Tohid, H., Amin, R. M., Bidin, M. B. L., Muthupalaniappen, L., \& Omar, K. (2013). Factors influencing insulin acceptance among type 2 diabetes mellitus patients in a primary care clinic: a qualitative exploration. BMC family practice, 14(1), 1-10.

Herath, H. M. M., Weerasinghe, N. P., Dias, H., \& Weerarathna, T. P. (2017). Knowledge, attitude and practice related to diabetes melitus among the general public in Galle district in Southern Sri Lanka: A pilot study. BMC Public Health, 17(1), 535. https://doi.org/10.1186/s12889-017-4459-5

IDF. (2018). Internasional Diabetes Federation (IDF) Diabetes Atlas Eighth edition. International Diabetes Federation. https://books.google.co.id/books?id=m9qyygeacaa j

Infodatin. (2018). Situasi dan Analisis Diabetes. Pusat Data dan Informasi Kementerian Kesehatan RI.

Khan, M., Wahab, F., Khan, M. T., \& Nawaz, A. (2017). Knowledge Attitude and Practice of Diet and Exercise among Diabetic Patients for Normal Plasma Glucose Level. 7(1), 5.

Lestari, D. T. (2014). Inisiasi Insulin Pada Pasien Diabetes Melitus Tipe 2 Di Rumah Sakit Umum Daerah Kabupaten Kudus. Prosiding Seminar Nasional \& Internasional, 2(1), Article 1. https://jurnal.unimus.ac.id/index.php/psn1201201 0/article/view/1160

Memon MS, et al. 2015. An assessment of knowledge, attitude and practices (KAP) towards diabetes and diabetic retinopathy in a suburban town of Karachi. J Med Sci. 2015 Jan-Feb; 31(1):183-8.

Muhith, A., \& Setyowati, I. (2014). Pemberian Buah Apel Romebeauty Terhadap Penurunan Kadar Gula Darah Pada Penderita Diabetes Melitus. Medica Majapahit, 6(2).

Nathan, D. M., Bennett, P. H., Crandall, J. P., Edelstein, 
S. L., Goldberg, R. B., Kahn, S. E., ... White, N. H. (2019). Does diabetes prevention translate into reduced long-term vascular complications of diabetes? Diabetologia, 62(8), 1319-1328. https://doi.org/10.1007/s00125-019-4928-8

Niven, N. (2013). Psikologi Kesehatan: Pengantar untuk Perawat \& Profesional Kesehatan lain (2nd ed.). Egc.

Notoatmodjo, S. (2012). Promosi kesehatan dan perilaku kesehatan.

Okatiranti, O. (2016). Gambaran Pengetahuan, Sikap Dan Kepercayaan Terhadap Diet Penderita DM di Rsud Kota Bandung. Jurnal Keperawatan BSI, 4(1).

Phitri H.E. \& Widiyaningsih, 2013, Hubungan Antara Pengetahuan dan Sikap Penderita Diabetes Mellitus Dengan Kepatuhan Diet Diabetes Mellitus di RSUD Am. Parikesit Kalimantan Timur, Jurnal Keperawatan Medikal Bedah, 1, pp.58-74.

Pradipta, I. S., Sodik, D. C., Lestari, K., Parwati, I., Halimah, E., Diantini, A., \& Abdulah, R. (2013). Antibiotic resistance in sepsis patients: evaluation and recommendation of antibiotic use. North American journal of medical sciences, 5(6), 344.

Perkeni. (2019). Pedoman pengelolaan dan pencegahan diabetes melitus tipe 2 dewasa-2019. Perkeni, 133.

Powers, M. A., Bardsley, J., Cypress, M., Duker, P., Funnell, M. M., Fischl, A. H., ... Vivian, E. (2015). Diabetes self-management education and support in type 2 diabetes: A joint position statement of the American Diabetes Association, the American Association of Diabetes Educators, and the Academy of Nutrition and Dietetics. Diabetes Care, 38(7), 1372-1382. https://doi.org/10.2337/dc15-0730

Reach, G., Pechtner, V., Gentilella, R., Corcos, A., \& Ceriello, A. (2017). Clinical inertia and its impact on treatment intensification in people with type 2 diabetes mellitus. Diabetes \& metabolism, 43(6), 501-511.

Rudini, D., Yusnilawati, Y., \& Sulistiawan, A. (2018). Analisis Pengaruh Kepatuhan Pola Diet Dm Terhadap Kadar Gula Darah Dm Tipe Ii. Jurnal Keperawatan Universitas Jambi, 3(2), Article 2. https://online-

journal.unja.ac.id/JNJ/article/view/6497

Sartunus, Hasneli, \& Junaidi, (2015) Hubungan Pengetahuan Terapi Insulin Terhadap Kepatuhan Pasien Diabetes Melitus Tipe 2 dalam Pemberian Injeksi Insulin. Jurnal Program Studi Ilmu Keperawatan Universitas Riau. Diakses pada 11 Oktober 2016.
Soegondo S. (2017). Diagnosis dan Klasifikasi Diabetes Melitus Terkini: Dalam Penaltalaksanaan Diabetes Terpadu. Balai Penerbit FK UI.

WHO. (2018). World Health Day 2016: WHO calls for global action to halt rise in and improve care for people with diabetes. https://www.who.int/news/item/06-04-2016world-health-day-2016-who-calls-for-globalaction-to-halt-rise-in-and-improve-care-forpeople-with-diabetes 